\title{
Justice after Violence: Critical Perspectives from the Western Balkans
}

\author{
DIANE ENNS \\ McMaster University, Canada
}

\section{Introduction}

... to many people who lived through the war in BiH justice would be a world, a life, a history in which the war had not happened.-Stef Jansen

Two decades after violence broke out following the dissolution of Yugoslavia, considerable obstacles continue to challenge those struggling for justice in the region. In Bosnia-Herzegovina ${ }^{1}$ especially, the success of nationalist ideologies and the ethnic cleansing that was their outcome-ending in an awkward internationally engineered system of governance - have left in their wake a host of vexing, interrelated problems. By now, their effects are well known to scholars and peace-building practitioners working in the region: an impoverished political framework that remains starkly divided along ethnic lines and is rife with corruption, a deep distrust of political leaders, persistent inequality, and little interest in reconciling with those who became wartime enemies.

How to deal with past atrocity and its legacy in the Western Balkans is a matter of ongoing debate and frustration, often exacerbated by the gap between local and international perspectives and by competing paradigms in the peacebuilding, human rights and transitional justice fields. Post-war justice mechanisms have focused on the prosecution and punishment of a select few war criminals, neglecting questions of broader responsibility and fostering resentment over the lack of justice at the community level or over what is perceived to be a biased application of the law. Rising inequality and poverty, institutional breakdown, and the long-term effects of trauma, 
add to the immense challenges of rebuilding societies after war. Under these circumstances, peaceful relations across nationalist lines, a flourishing civil society, and responsible state leaders mutually engaged in creating a better future, seem utterly remote. We are presented here with an opportunity to reflect on the complicated relationships between justice, rule of law, reconciliation, inequality, politics, and peace.

Each of the contributors to this issue of Studies in Social Justice takes on the challenge of this opportunity, engaging with different aspects of these relationships and their contradictions, primarily in the context of post-war Bosnia-Herzegovina, which bore the brunt of the violence, from 1992-95, but also in neighbouring Croatia and Serbia, and in the Western Balkans more generally. If there is a common thread that runs through these essays it is that a juridical form of justice is limited in what it can do in the aftermath of violent conflict. For many scholars and practitioners this is by no means a surprising conclusion, but it does run contrary to the reigning paradigm of what I will call the global post-conflict justice industry. Since the 1990s, transitional justice has become the favoured approach for countries dealing with past atrocities, promoting criminal prosecutions, truth-seeking commissions, reparations, and reconciliation programs as effective methods of responding to war crimes and human rights abuses. But many have criticized its almost exclusive dependence on a criminal justice framework at the expense of other approaches to dealing with the past - approaches initiated by the affected communities themselves, by a politically active civil society supported by strong institutions and by capable leadership. My own view is that transitional justice, now taking precedence over other paradigms like reconciliation, conflict transformation, or even peacebuilding, puts too much faith in the law as the best method of dealing with the aftermath of political violence. The promise of law to rectify the injustices of the past is an appealing one, but the catharsis that victims experience in being heard and in hearing the truth about war crimes, and their relief or elation when perpetrators are sentenced, are limited, if valuable, experiences. Despite this promise, truth commissions and criminal prosecutions on their own do not often foster social repair and might even hamper much needed social and political change.

That we are now in danger of placing too great an emphasis on judicial mechanisms to deal with the effects of violent conflict is borne out in the essays that follow. But the authors in this issue also caution against placing too much faith in the promise offered by discourses on peace and reconciliation. The moral imperative to reach across ethnicized and nationalized enemy lines and forgive past grievances in the interests of peace is often externally imposed, based on an international mischaracterization of the conflict as an eruption of historic ethnic hostilities and a reductive understanding of the factors that caused the violence. A simplistic version of reconciliation might conflict with the need for justice - not only legal, punitive justice, but social justice - including the immediate material needs of a population whose daily lives have been altered beyond recognition.

The essays in this issue thus point to an important lacuna in the fields 
of transitional justice and peacebuilding. This lacuna is politics; specifically, a robust civil society politics, which, by all accounts, is sorely lacking in the region. The demands for justice as rule of law on the one hand, and for reconciliation and peace on the other, tend to neglect politics, if by politics we mean collective congregating, speaking and acting with the interests of a pluralist public in mind. Justice must be viewed and practiced within a broader social and political context, alongside other elements necessary for rebuilding societies and states devastated by war. Without an active civil society and the will to bring about social, political, and economic change, justice may end up meaning very little.

Our point of departure is Timothy Donais's accurate assessment of the gap that exists between "the lofty ambitions of the international community in terms of bringing justice and rule of law to afflicted countries, and the messy, compromising realities of the effort to translate vision into practice" (p. 189). In post-Dayton Bosnia, despite the emphasis on rule of law, and what Donais believes are "substantial achievements" on this front, the peace process remains as fragile as ever (p. 191). Structural injustice continues, perpetuated by an underlying structure of political power that remains largely unaltered since the end of the war. Bosnia's political system remains dysfunctional, with leaders unable to govern competently a population rigidly divided along ethnic lines with little evidence of improved relations in several decades. Nationalist rhetoric, Donais notes, is still "the key currency of political life" (p. 202). In such a dismal political context — steeped in acrimony, fear, and mutual distrust - the rule of law cannot simply function as a neutral arbiter. This is evident in Donais's analyses of two prominent manifestations of rule of law practice in Bosnia: police reform and efforts to curb widespread political corruption. In recognition of its limits, Donais suggests that rule of law should be more broadly connected to peace and justice. To this end he calls for significant changes to the current political dynamics, the development of consensual arrangements acceptable to all key political actors, and a reengaged civil society.

The widespread corruption to which Donais alludes is the subject of our next contribution by Vesna Bojicic-Dzelilovic, who analyzes the relationship between informality and inequality and its effects on the social reintegration process in Bosnia-Herzegovina. The rise of an informal economy in conjunction with corruption, which has given rise to a discriminatory system of rule which rests on informal relations was due to the disintegration of the Bosnian state through the fusion of violence, crime, and extremist politics. Informality, as Bojicic-Dzelilovic defines it, has an ambiguous effect in terms of social justice outcomes; it is linked to poverty, corruption, inequality, and social injustice, but is tolerated at the everyday level.

If informality was triggered by war, it has been sustained by post-war elites. But the fact that the same group of actors controls both the polity and the economy is often overlooked in current analyses of the Bosnian state. Bojicic-Dzelilovic complains of the myopia concerning inequality in certain academic and policy debates that focus overwhelmingly on the politics of 
Bosnia's statehood, for politics is inseparable from its economic foundations. To complicate this relationship further, she calls attention to the destructive impact of informality on interpersonal and institutional trust, since trust does not develop when some individuals benefit from the inequities created by informal arrangements. Unequal access to assets and resources, BojicicDzelilovic explains, especially the accumulation of wealth and power on the part of ethnic elites who were prominent war-time players, exacerbates a sense of discrimination and social injustice and ultimately undermines social reintegration.

Bojicic-Dzelilovic concludes that any analysis of noncompliance with state sanctioned rules, in states transitioning from communism and/or war has to factor in the transformation of the state itself. In Bosnia-Herzegovina, the transition to a stable "positive peace" requires a reconstruction of the relationship between state and society (p. 218). This is proving to be an extraordinary challenge, as Donais also pointed out, since twenty years after the end of the 1992-95 war there is still no "collective vision of a shared national project" that would repair social relations. Thus, while the political leadership has a significant role to play, given Bosnians' lack of trust in their leaders, and even disgust for politics, the public pressure required to disturb the status quo and invigorate democratic process is not forthcoming.

Stef Jansen addresses the relationship between justice and politics from a different angle, throwing into question the demand for reconciliation as a requirement of justice. Concerned with the explicitly political dimension of justice, manifest in a liberal reconciliation discourse in Bosnia-Herzegovina that serves to reinforce a nationalist version of history, Jansen considers whose reconciliation is being desired in this region, by whom, for whom and for what? Pre-war encounters with neighbours, strangers, or family members across national lines - distinctions that only acquired their current significance through war-were simply "practical dimensions of everyday life" (p. 233). Jansen asks: why would anyone now perceive these "international" or "ethnonational" encounters as virtuous acts of reconciliation? "To accept such a reductionist definition of 'sides' in an identitarian matrix," he suggests, "would represent the ultimate crown on the nationalist hegemonizing projects of the 1990s" (p. 232).

The desire for justice evokes more than judiciary procedures, Jansen insists. In a post-war context, however, the meaning of justice is difficult to pin down. Beyond retributive justice, punishment and reparations, justice may evoke much broader utopian notions of balance. But the object of hope for most people, he observes, is "a normal life." People do not engage with one another based on an abstract notion of common humanity - the kind of equal and inalienable humanity that reconciliation projects assume we all share - but as persons who establish some degree of mutual recognition based on specific social positionings and identifications. This mutual recognition beyond reductive nationalist identities is the most promising, yet most challenging, requirement for an alternative to Bosnian "politika," challenging given that politics is blamed for the cause of the war and the 
suffering that was its outcome. In Jansen's view however, a situation that is widely seen as caused by politics cannot be overcome or even improved without recourse to politics. Active politicization would bring about a more just future.

The next two essays point to the power of ethnicized narratives in shoring up this resistance to such politicization, and to the limits of the law in easing this resistance. Dejan Guzina and Branka Marijan elaborate a critique of the use of international criminal justice in Bosnia-Herzegovina, claiming that transitional justice approaches and the International Criminal Tribunal for the Former Yugoslavia (ICTY) have not overcome divisions but constructed parallel worlds in the region. In fact, they remark that the ICTY and domestic trials "are increasingly seen as political theater of the absurd rather than the mechanism that would allow the truth about the war to be unearthed." While transitional justice approaches are touted as capable of inspiring respect for rule of law, and of creating a valuable historical record, Guzina and Marijan outline the political abuses of these methods: Bosnian elites use the past to play to their own ethnic groups in order to pursue nation building projects. There is a reluctance to acknowledge one's own guilt and responsibility, as evidenced by the Naser Oric trial.

Elites are not alone, however, in determining the outcomes of transitional justice processes. Local actors have yet to come to terms with a historical narrative that would transcend ethnic divisions, a process stymied by the fact that Bosnian local communities continue to be physically and psychologically segregated from one other. But Bosnians are not simply puppets passively responding to elites. Guzina and Marijan examine popular perceptions of war and its aftermath in Sarajevo and Banja Luka in particular, to show the disjunct between internationally sponsored goals of reconciliation and local acts of contestation and citizenship practices. Before the war, these cities were the multiethnic and multicultural centers of Bosnia; after 1995 they emerged as symbols of division and mutually contradictory nation building projects. The narratives that help sustain these changes cannot be simply dismissed, Guzina and Marijan argue - the stories that people tell themselves enable them to cope. The authors conclude that analyses of the conflict in Bosnia must take into account what gives these narratives their power, and what are the objective political, social and economic factors that continue to provide a fertile ground for their widespread support.

Jelena Subotic is also concerned with public narratives of the past in Bosnia, Croatia, and Serbia that remain mutually exclusive, contradictory, and irreconcilable. Practices of remembrance or memorialization, whether in the form of public commemoration efforts or history classes in schools, have served to entrench incompatible versions of the past and contribute to further mistrust and the prevention of truth and justice. Memory projects tend to reflect each state's interest in deflecting responsibility for atrocities committed by its own leaders and citizens, justified as defensive action. History education, which Subotic argues is naturally "fraught with analytical, ethical, and interpretive minefields" (p. 268), is particularly problematic in 
Bosnia-Herzegovina, where education policy is decentralized and controlled by local authorities. History has come to represent the ethnic politics of the majority population; in Bosnia itself, three different sets of history textbooks circulate, each providing an ethnicized version of Bosnia's past.

Subotic argues that to rectify this ethnicized memory work we need a reparative sense of justice that leads to practices that show states are willing to acknowledge responsibility for past violence. To this end all three states should accept an official regional commission of inquiry into past atrocities and should initiate comprehensive educational reform and memorialization efforts such as establishing memorial sites. These are necessary for a comprehensive post-conflict justice framework. Crucial in this process are memory projects that forego dwelling on their own victimization in isolation and include a broader regional focus. As our other authors have argued, Subotic stresses that in order to take these critically necessary steps in pursuit of regional justice, profound political change must take place first.

Finally, in a review essay of Angelina Jolie's much publicized film In the Land of Blood and Honey (2011), in tandem with Juanita Wilson's and HansChristian Schmid's related feature films, As If I Am Not There (2010) and Storm (2009), Brian Phillips considers whether film can contribute to justice processes in the aftermath of violent conflict. Like the other contributors to this issue, Phillips makes the case that courts of law leave an unfortunate lacuna in the requirements of justice. Rape in particular falls into this lacuna, as courts struggle unsuccessfully to accommodate the experience of victims of rape in war.

Filmmakers have risen to the challenge of filling the need for complementary processes alongside juridical procedures in the long struggle for justice and recovery after war. While Jolie's film appears to offer victims of sexual violence a sense of justice by giving them a voice, Phillips argues emphatically that this film does not fulfill such a promise, and in places actually exploits victims' suffering. Thus for Phillips, the film raises serious moral concerns about the recreation of scenes of atrocity in cinema in general, and the retelling of the Bosnian tragedy in particular. He questions the therapeutic function of "giving voice" that is commonly highlighted in human rights and peacebuilding discussions more broadly; a therapeutic model tries to reconcile people with their past, not materially transform their lives. It is social justice that populations need, Phillips asserts, not therapeutic measures.

Phillips concludes that rather than imagining that a film can on its own offer some alternative form of justice for victims by recreating their experience, "the real potential of film as a contribution to the transitional justice toolkit perhaps lies in its capacity to shred the comforting, formulaic prescriptions about dialogue, dealing with the past, and reconciliation that are too often voiced in peacebuilding enterprises-those wishful strategies for social reconstruction that show little understanding of just how long and hard the road to post conflict justice can be..."

These are appropriate sentiments on which to end this issue, for it is clear 
from all of these contributions that there are no easy or comforting formulas to apply in the struggle for justice in the wake of destructive violence- only partial, imperfect, and contingent answers that must arise out of collective political engagement. There is no justice without politics.

\section{Notes}

1 Scholars writing on Bosnia-Herzegovina variously refer to the country as Bosnia, Bosnia-Herzegovina or its abbreviation, $\mathrm{BiH}$. The authors in this issue each have their own preferences. 